\title{
Dräktvariation hos skärpiplärka Anthus petrosus littoralis och vattenpiplärka Anthus spinoletta i vinterdräkt
}

\author{
Plumage variation of Rock Pipit Anthus petrosus littoralis and Water Pipit Anthus \\ spinoletta in winter plumage
}

\author{
REINO ANDERSSON
}

\begin{abstract}
Plumage variation in nine neutral (i. e. not concerning colour hues) characters was studied from October throug February in 77 Rock Pipit Anthus petrosus littoralis and 47 Water Pipit Anthus spinoletta in southern Sweden. The Rock Pipit generally showed more variation than the Water Pipit. Several characters were overlapping between the species, while especially streaking on the underparts significantly distinguished between them. The most reliable differences con-
\end{abstract}

cerned the width and sharpness of the streaks on the lower breast, and on the anterior and, especially, rear flanks, the Water Pipit having considerably thinner and more clearcut streaks than Rock Pipit.

Reino Andersson, Rödaledstigen 6, S-432 53 Varberg, Sweden.Email: reino.andersson@ciaoip.se

Received 16 March 2012, Accepted 29 March 2012, Editor : S. Svensson

\section{Inledning}

Vintern 2004/2005 startade en studie av skärpiplärkans Anthus petrosus littoralis vinterekologi i mellersta Halland (Andersson \& Nothagen 2011). I samband med detta insamlades även data om inbördes dräktvariation hos skärpiplärka och vattenpiplärka Anthus spinoletta. Bakgrunden var bestämningsproblematiken hos de båda arterna, som under ett flertal år diskuterats i olika sammanhang. I Sverige har flera artiklar publicerats i ämnet (t.ex. Ullman 1995, Larsson 1996, Alström \& Mild 1997). Alström \& Mild (2003) presenterar en övergripande genomgång av bl.a. dräkter och ruggning.

Någon utförligare beskrivning av dräktvariationen hos respektive art har dock inte publicerats tidigare. Då debatten kring bestämningsproblemen snarast har ökat under senare år, kan denna uppsats utöver att spegla variationen, förhoppningsvis även bidra till att säkerställa en korrekt artbestämning.

\section{Material och metoder}

Under vinterstudien antecknades allmänna dräktdata för totalt 96 skärpiplärkor och 46 vattenpiplärkor. Med utgångspunkt från denna erfarenhet har jag valt ut ett antal karaktärer och bedömt variationen hos var och en av dem. För att erhålla en enhetlig och objektiv bedömning har jag dock uteslutande använt fotografier av god kvalitet och av säkert artbestämda individer, totalt 77 skärpiplärkor och 47 vattenpiplärkor. Av dessa foton är 25 skärpiplärkor och 16 vattenpiplärkor fåglar som jag själv studerat. Övriga fotografier har hämtats ur Artportalen Svalans bildgalleri (www.artportalen.se/birds/). Alla använda fotografier avser fåglar iakttagna i södra Sverige under perioden oktoberfebruari. Månadsvis fördelning av dessa fotograferade piplärkor redovisas i Tabell 1 .

Varje individ som medtagits har fotograferats ur minst två vinklar, framifrån och från sidan. De har genomgått en likartad och jämförbar klassificering av nio neutrala karaktärer. Dessa omfattar inga färgnyanser i fjäderdräkten (t.ex. brun övergump/stjärttäckare, vitaktig undersida hos vattenpiplärka), detta för att undvika svårbedömda och subjektiva värderingar. Ett undantag utgör dock registrering av grå nacke hos vattenpiplärka, eftersom detta länge ansetts vara en viktig bestämningskaraktär och kan avgöras som en färgkontrast gentemot manteln.

De nio aktuella kriterierna är ögonbrynsstreck, ögonring, näbbens utseende, mantelteckning, mellersta och större täckarbräm, nedre bröststreckning samt främre och bakre flankstreckning. De två förstnämnda har poängsatts beroende på om karaktären saknats (1), varit otydlig (2) eller tydlig (3); vid den statistiska analysen i denna uppsats slog jag ihop (2) och (3). Den gula utbredningen på näb- 
Tabell 1. Månadsvis fördelning av de studerade skärpiplärkorna och vattenpiplärkorna.

Distribution between month of the studied Rock Pipits and Water Pipits.

\begin{tabular}{lcc}
\hline $\begin{array}{l}\text { Månad } \\
\text { Month }\end{array}$ & $\begin{array}{c}\text { Skärpiplärka } \\
\text { Rock Pipit }\end{array}$ & $\begin{array}{c}\text { Vattenpiplärka } \\
\text { Water Pipit }\end{array}$ \\
\hline Oktober & 22 & 1 \\
November & 16 & 17 \\
December & 8 & 10 \\
Januari & 13 & 9 \\
Februari & 18 & 10 \\
\hline Totalt & 77 & 47 \\
\hline
\end{tabular}

ben har angetts som otydlig (begränsat svagt gul, 1) eller tydlig (utbrett kraftigt gul, 2). Manteln har endast bedömts utifrån otydlig (1) eller tydlig (2) streckning. Likaså har täckarbrämen poängsatts efter otydliga (mörka, 1) eller tydliga (ljusa, 2) bräm.

Streckningen på undersidan har tilldelats två olika poäng för vart och ett av de tre fjäderfälten. Det ena om fläckarna varit breda (1) eller smala (2), det andra om de haft diffust (1) eller skarpt avsatta (2) kanter. Nedre bröstet definieras av dess nedersta streckning mot buken. Med främre flanken menas fjäderfältet nedanför större täckarraden mot buken, medan bakre flanken utgjorts av fältet ovanför benet. De olika fjäderfältens placering på en piplärka och den terminologi för dessa som används i denna uppsats visas i Figur 1. Dräktvariationen har be-

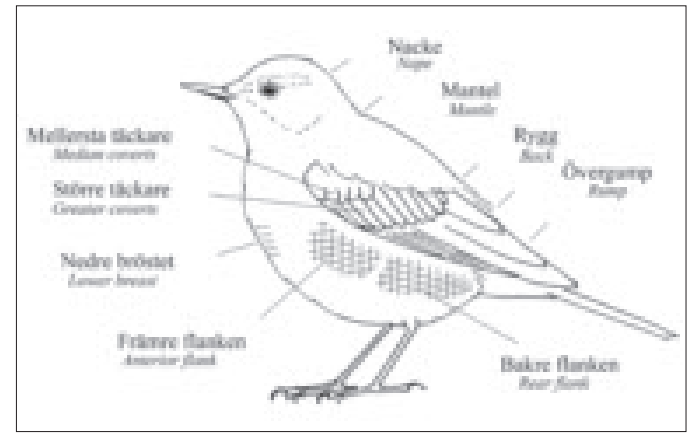

Figur 1. Fjäderfältens placering hos de studerade piplärkorna. Teckning: Anders Nothagen.

Location of the feather fields in the examined pipits. Drawing: Anders Nothagen.

dömts inom respektive arts karaktärsdrag, vilket innebär att vissa karaktärer, t.ex. ögonring, inte behöver vara identiska trots att de klassats likartat hos de bägge arterna. Statistiskt användes signifikansprövning med Fischer's Exact Test.

\section{Resultat}

Av Tabell 2 framgår att de allra flesta vattenpiplärkor uppvisade ögonbrynsstreck och bland dem var $57 \%$ tydliga. Drygt hälften av skärpiplärkorna hade ögonbrynsstreck, men endast $2 \%$ av dessa ögonbrynsstreck framstod som tydliga. Samtliga piplärkor av de båda arterna hade ögonring. Hos 77

Tabell 2. Procentuell närvaro av nio studerade karaktärer hos 47 vattenpiplärkor* och 77 skärpiplärkor. Percent presence of nine studied characters of 47 Water Pipits* and 77 Rock Pipits.

\begin{tabular}{lrr}
\hline Närvaro av karaktären & $\begin{array}{r}\text { Vatten- } \\
\text { piplärka } \\
\text { Presence of the character }\end{array}$ & $\begin{array}{r}\text { Skär- } \\
\text { piplärka } \\
\text { Rock } \\
\text { Pipit }\end{array}$ \\
\hline Pipit & 56 \\
Ögonbrynsstreck Supercilium & 94 & 100 \\
Ögonring Eye ring & 100 & 23 \\
Näbb med tydlig utbredning av gult Bill with distinct yellow pattern & 76 & 48 \\
Mantel med tydlig streckning Mantle with distinct streaking & 11 & 79 \\
Mellersta täckare med ljusa bräm Median coverts with light edges & 81 & 25 \\
Större täckare med ljusa bräm Greater coverts with light edges & 83 & 35 \\
Nedre bröst med smala streck Lower breast with thin streaks & 100 & 17 \\
Nedre bröst med skarpt avsatta streck Lower breast with clearcut streaks & 100 & 13 \\
Främre flank med smala streck Anterior flank with thin streaks & 98 & 4 \\
Främre flank med skarpt avsatta streck Anterior flank with clearcut streaks & 98 & 1 \\
Bakre flank med smala streck Rear flank with thin streaks & 92 & 0 \\
Bakre flank med skarpt avsatta streck Rear flank with clearcut streaks & 89 & \\
\hline
\end{tabular}

*Näbbens gula och nedre bröstets streckning baseras på 45 individer hos vattenpiplärka på grund av olämplig fotovinkel för två individer. Yellow of bill and streaking of lower breast is based on 45 individuals in Water Pipit due to inappropriate angle of view in the photographs of two birds. 


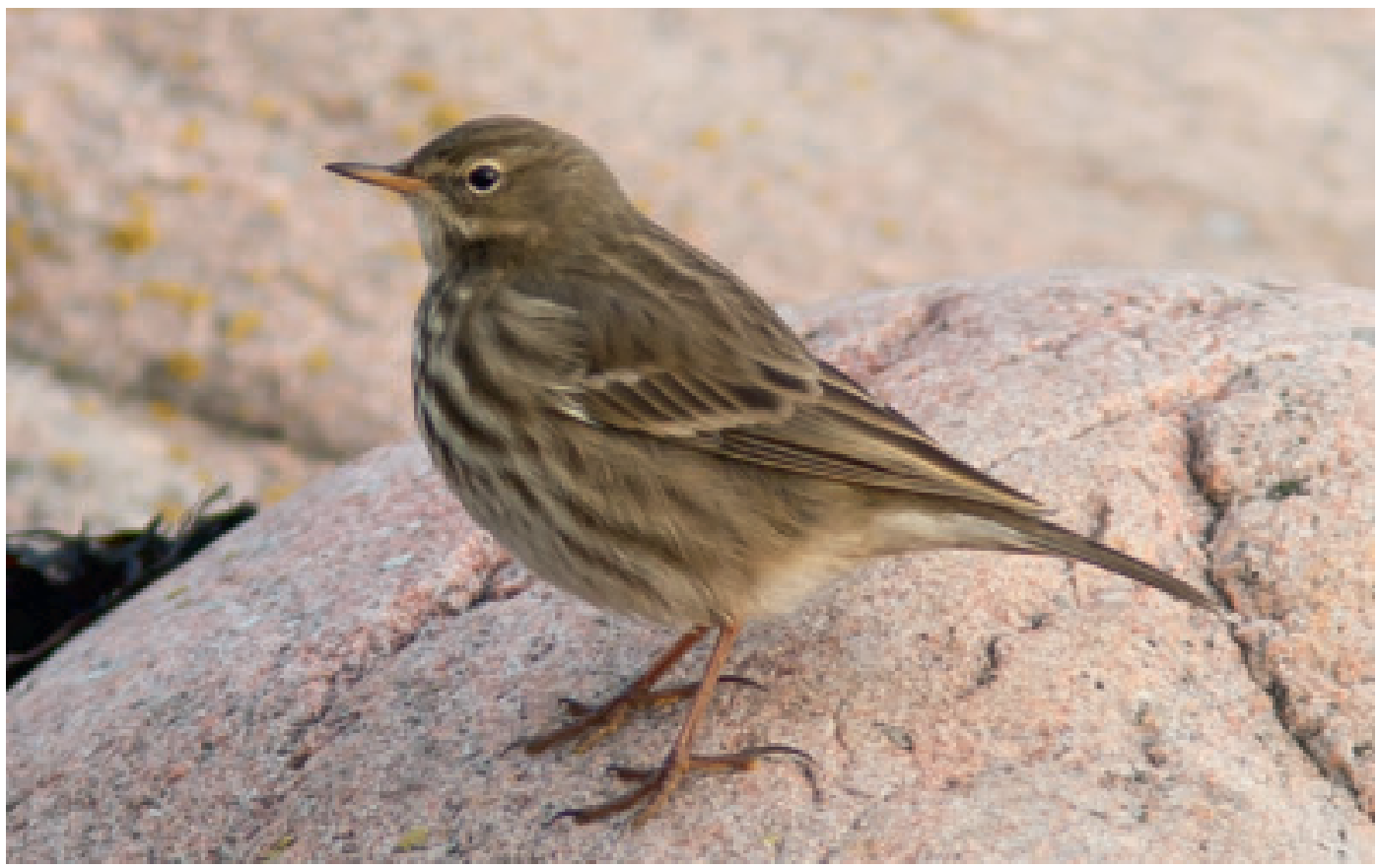

Figur 2. Skärpiplärka i typisk vinterdräkt fotograferad på Årnäshalvön norr om Varberg den 25 november 2008. Foto: Anders Nothagen.

Rock Pipit in typical winter plumage 25 november 2008.

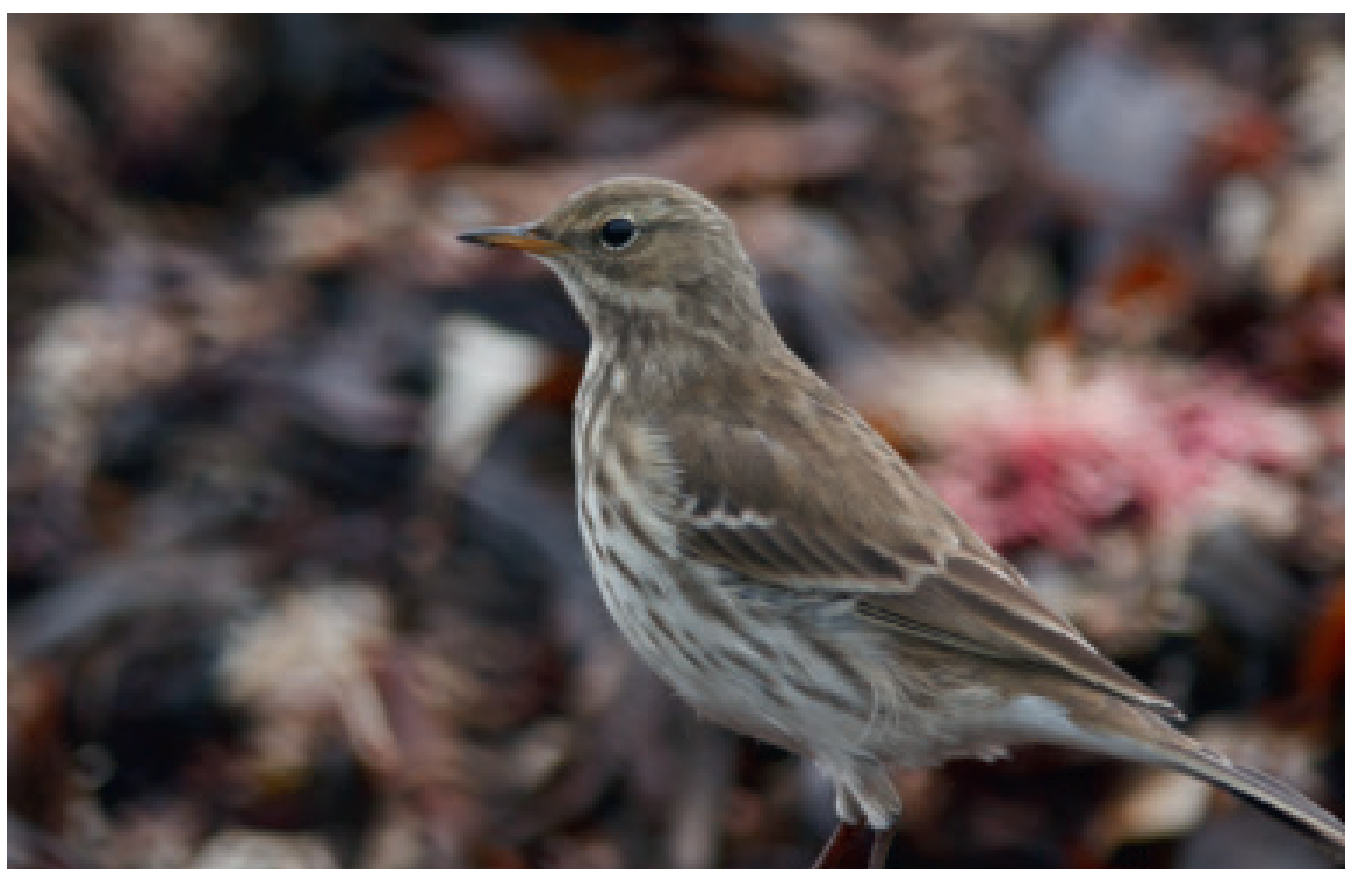

Figur 3. Vattenpiplärka i typisk vinterdräkt fotograferad på Årnäshalvön norr om Varberg den 8 november 2008. Foto: Anders Nothagen.

Water Pipit in typical winter plumage 8 november 2008. 
\% av vattenpiplärkorna var den tydlig, jämfört med $90 \%$ för skärpiplärka. Näbbens gula utbredning var tydlig hos en betydligt större andel vattenpiplärkor än skärpiplärkor. Manteln var däremot tydligt streckad i större utsträckning hos skärpiplärka. Förekomsten av ljusa bräm på de mellersta täckarna var likartad hos de bägge arterna. De större täckarnas bräm var däremot ljusa i högre grad hos vattenpiplärka. Av vattenpiplärkorna uppvisade 74 $\%$ grå nacke.

Skillnaden i variation hos arterna visas i Tabell 2. Skillnaden var höggradigt statistiskt signifikant $(\chi 2>17 ; p<0,001)$ för samtliga karaktärer utom för ögonring och mellersta täckarnas bräm. Särskilt stor var dock skillnaden för undersidans streckning på alla tre studerade fjäderfält. Samtliga vattenpiplärkor uppvisade smala och skarpt avsatta fläckar på nedre bröstet, till skillnad från skärpiplärkan som uppvisade en större variation. Denna variation tog sig i 5\% av fallen även uttryck i en större utbredning av streckningen längre ned på buken. En majoritet av vattenpiplärkorna uppvisade smala respektive skarpt avsatta fläckar på främre flanken, medan ett motsatt förhållande rådde hos skärpiplärkan. Bakre flanken uppvisade en hög andel smala och skarpt avsatta fläckar hos vattenpiplärka. Hos skärpiplärka var endast $1 \%$ smala, medan inga av dem uppvisade skarpt avsatta fläckar på den bakre flanken (Figur 2 och 3).

\section{Diskussion}

Av resultaten framgår att dräktvariationen är generellt större hos skärpiplärka jämfört med vattenpiplärka. En mycket liten andel av vattenpiplärkorna saknar ögonbrynsstreck, samtidigt som ytterst få skärpiplärkor uppvisar tydliga sådana

Undersidans streckning skiljer sig signifikant mellan de båda arterna. Det är intressant att nedre bröstet uppvisar minst variation hos vattenpiplärka och störst hos skärpiplärka. När det gäller främre flanken är variationen jämnare mellan de båda arterna, medan bakre flanken visar på minst variation hos skärpiplärka och störst hos vattenpiplärka, det vill säga omvänt förhållande jämfört med nedre bröstet. Streckningen på undersidan är hos piplärkor generellt bredare och diffusare i fräsch dräkt under hösten, för att i takt med slitage bli marginellt smalare och distinktare (Alström \& Mild 2003). I denna studie är dock individerna jämnt fördelade över vintermånaderna, vilket gör eventuella avvikelser statistiskt försumbara.

Färgnyanser har undvikits i denna uppsats, men uppvisar en viss variation hos båda arterna.
I synnerhet under senvintern då dräkten slitits och blekts, kan skärpiplärkan ibland upplevas som påtagligt ljus på undersidan. I sällsynta fall kan även övergumpen uppfattas som svagt brunaktig, dock aldrig på samma sätt som hos vattenpiplärka. Grå nacke hos vattenpiplärka har ofta angetts som en artskiljande karaktär, men här finns en stor variation från total avsaknad till markant gråblå nyans. Många av de grånackade individerna är också kastanjebrunt färgade på mantel, rygg och streckning. Sådana individer kan utifrån allmänna ålderskriterier och ruggning påfallande ofta bestämmas till adulter. I det fătal fall som yngre fåglar konstaterats ha grå nacke, brukar den övriga dräkten inte vara särskilt kontrastrik. En i nuläget högst spekulativ tanke är att denna "färgade" dräkt skulle kunna vara ålders- och kanske även könsberoende. Detta är en spännande dräktdetalj att studera mer ingående för hugade och bestämningsinriktade ornitologer.

Eftersom färger utgör subjektiva karaktärer, kan resultaten i föreliggande uppsats vara till hjälp för att uppnå en korrekt artbestämning. Utöver allmänna färgnyanser rekommenderas därför att beakta förekomsten av smala respektive skarpt avsatta fläckar på nedre bröst, främre och bakre flank. Närvaron av dessa kombinerade karaktärer utgör en säker indikation för vattenpiplärka. Omvänt uppvisar skärpiplärkan inte denna kombination av karaktärer, i synnerhet inte på den bakre flanken. Ofta bildar istället breda och diffusa streck en sammanhängande fläck på bakre flanken (s.k. "flankblaffa"), vilken utgör en av de enskilt tillförlitligaste karaktärerna bland andra redan kända och vedertagna bestämningskriterier (jfr. Alström \& Mild 2003).

\section{Tack}

Ett varmt tack riktas till Anders Nothagen och Bo Nielsen som deltagit såväl i studien av skärpiplärkans vinterekologi, som i fältarbetet om piplärkornas dräktförhållanden. De har granskat uppsatsen och bistått med många givande synpunkter, liksom Robin Andersson, Pär Sandberg och Kåre Ström. Bo Nielsen har dessutom varit behjälplig med de statistiska testerna. Ett särskilt tack riktas till Per Alström för sakkunnig granskning av manuskriptet.

\section{Referenser}

Alström, P. \& Mild, K. 1997. Fältbestämning av skärpiplärka Anthus petrosus, vattenpiplärka Anthus spinoletta och hedpiplärka Anthus rubescens. Roadrunner 1/1997: 22-31. 
Alström, P. \& Mild, K. 2003. Pipits \& Wagtails of Europe, Asia and North America: identification and systematics. London.

Andersson, R. \& Nothagen, A. 2011. Vinteruppträdande hos skärpiplärka i mellersta Halland. Fåglar på Västkusten 4/2011: 24-26.

Larsson, H. 1996. Fältbestämning av vattenpiplärka Anthus spinoletta. Vår Fågelvärld 1/1996: 16-18.

Ullman, M. 1995. Fältbestämning av vattenpiplärka. Anser 34: 41-45.

\section{Summary}

In $2004 / 2005$, we began to study the winter ecology of the Rock Pipit in southwestern Sweden (Andersson \& Nothagen 2011). During this study, I collected records about the plumage variation of 96 Rock Pipits and 46 Water Pipits. This information was used to identify a number of characters that could be used for a description of plumage variation in the two species. In order to make the evaluation uniform and objective, I used only high quality, detailed photographs, 77 of Rock Pipits and 47 of Water Pipits, all with both a side and a front view. Of these photographs, 25 of Rock Pipits and 16 or Water Pipits, were of birds that had been studied within my own project. The remaining photographs were obtained from the photo gallery at the Species Gateway (Artportalen, Svalan; (www.artportalen.se/birds/). All photographs are of birds observed in southern Sweden during October through February (Table 1). Every individual was thoroughly examined and judged by a similar and comparable classification of nine different neutral plumage characters. I excluded colour hues in the feather plumage in order to avoid subjective valuations and characters difficult to define. One exception was the registration of grey nape in Water Pipit, since this criterion since long has been considered an important character for identification of this species.

The nine characters are supercilium, eye-ring, amount of yellow on bill, mantle streaks, edges of median and greater coverts, lower breast, anterior and rear flank streaking. The two first characters have been scored from 1 to 3 depending of the appearance: not present (1), unclearly present (2) or distinctly present (3). For the statistical test, I pooled score (2) and (3). The yellow distribution on the bill has been classified as unclear (limited and slight yellow, 1) or distinct (spread and prominent yellow, 2). The mantle streaks have only been scored as unclear (1) or distinct (2). The edges of the coverts have also been scored as unclear (dark, 1) or distinct (light, 2). The streaking on the under- parts has got two different scores for the three different feather fields. One of them concerned broad streaks (1) or thin streaks (2), and another referred to diffuse (1) or clearcut (2) edges. The lower breast was defined as the streaked feathers nearest to the belly. The anterior flank is the feather field below the row of the greater coverts towards the belly, whilst the rear flank constitutes the field above the leg of the bird. The location of the feather tracts that are described in this paper and the terminology I use are shown in Figure 1. The differences were tested with Fischer's Exact Test.

Table 2 shows the percentage distribution of the nine studied characters. Besides this it will be added that $74 \%$ of the Water Pipits showed grey nape. With the exception of the eye ring and the edges of to the median coverts, the variation of the characters was significantly different $(\chi 2>17$, $\mathrm{p}<0.0001)$ between the two species. The supercilium was distinctly present in $57 \%$ of the Water Pipits but only in $2 \%$ of the Rock Pipits. The eye-ring was distinctly present in $77 \%$ of the Water Pipits and in $90 \%$ of the Rock Pipits. The streaking of the underparts was significantly different between the species in all three feather fields. All Water Pipits showed thin and clearcut streaks on lower breast, in opposite to the Rock Pipits who showed a larger variation. A majority of the Water Pipits showed thin and clearcut streaks on the anterior flank, whilst it was a much lower proportion in the Rock Pipit. Also the rear flank showed thin and clearcut streaks in a high share of the Water Pipits. For Rock Pipit it was only one individual, $1 \%$, with thin streaks and none with clearcut streaks (jfr. Figure 2 and 3. The results show that the plumage variation is generally larger in the Rock Pipit than in the Water Pipit. Whilst almost all Rock Pipits lacked a distinct supercilium, more than half of the Water Pipits showed this character.

Colour hues have not been used in this study, but also these characters show some variation in both species. Especially during the late winter, when the plumage has been worn and bleached, the Rock Pipit sometimes shows a light appearance on the underparts. In rare cases even the rump of the Rock Pipit shows a slight brownish appearance, though never like the one of the Water Pipit. Grey nape in Water Pipit has often been considered as a dividing character between the two species. However, this character shows great variation, from total absence of this hue to an obvious grey-blue hue.

Since colours are normally subjective characters in these species, the results in this study could be important to attain a correct identification. Besides 
colour hues, I therefore recommend to take careful notes on the occurrence of thin respectively clearcut streaks on the lower breast, anterior flanks and rear flanks. The presence of these characters will ensure the identification of a Water Pipit. The Rock Pipit does not show these combined charac- ters, especially not on the rear flank. Instead the Rock Pipit often shows broad and diffuse streaks in form of a connected, diffuse spot on the rear flank, which constitutes one of the single most reliable characters among those that are already known and accepted (jfr. Alström \& Mild 2003). 